\title{
The Mortara Affair and the Question of Thomas Aquinas's Teaching Against Forced Baptism
}

\author{
MATTHEW TAPIE \\ matthew.tapie@saintleo.edu \\ Saint Leo University, Saint Leo, FL 33574
}

\section{Introduction}

In January 2018, controversy over the Mortara affair remerged in the United States with the publication of Dominican theologian Romanus Cessario's essay defending Pius IX's decision to remove Edgardo Mortara, from his home, in Bologna. ${ }^{1}$ In order to forestall anti-Catholic sentiment in reaction to an upcoming film, Cessario argued that the separation of Edgardo from his Jewish parents is what the current Code of Canon Law, and Thomas Aquinas's theology of baptism, required. ${ }^{2}$

For some, the essay damaged Catholic-Jewish relations. Writing in the Jewish Review of Books, the Archbishop of Philadelphia, Charles Chaput, lamented that Cessario's defense of Pius revived a controversy that has "left a stain on CatholicJewish relations for 150 years." "The Church," wrote Chaput, "has worked hard for more than 60 years to heal such wounds and repent of past intolerance toward the Jewish community. This did damage to an already difficult effort." ${ }^{\prime 3}$ In the

\footnotetext{
${ }^{1}$ On June $23^{\text {rd }}, 1858$, Pope Pius IX ordered police of the Papal States to remove a six-year-old Jewish boy, Edgardo Mortara, from his home, in Bologna, because he had been secretly baptized by his Christian housekeeper after allegedly falling ill. Since the law of the Papal States stipulated that a person baptized must be raised Catholic, Inquisition authorities forcibly removed Edgardo from his parents' home, and transported him to Rome. See David Kertzer, The Kidnapping of Edgardo Mortara (New York: Vintage, 1998); Romanus Cessario, "Non Possumus," First Things (February 2018): 55-58. Cessario's essay is a review of the English translation of Edgardo Mortara's memoir by Vittorio Messori, Kidnapped by the Vatican? The Unpublished Memoirs of Edgardo Mortara (San Francisco: Ignatius Press, 2017). Kertzer argues that the documentary evidence contradicts the reports in the 1888 memoir. See his essay, "The Kidnapping of Edgardo Mortara: The Continuing Controversy," Studies in Christian-Jewish Relations 14, no. 1 (2019): 1-10; Kertzer, "Edgardo Mortara's Doctored Memoir of a Vatican Kidnapping," The Atlantic, April 15, 2018, https://www.theatlantic.com/international/archive/2018/04/edgardo-mortara-doctored-memoir/554948/.

${ }^{2}$ Cessario, 56.

${ }^{3}$ Archbishop Charles J. Chaput, "The Mortara Affair, Redux," Jewish Review of Books, 292018 , https://jewishreviewofbooks.com/articles/2979/mortara-affair-redux/.
} 
words of a member of the Mortara family, the incident remains "an open wound...something we still discuss at every Passover." ${ }^{4}$

Others criticized particular theological claims of Cessario's essay, citing Aquinas's teaching against forced baptism of Jewish children. ${ }^{5}$ Indeed, both Cessario and his critics appeal to Aquinas to argue for and against Pius IX's decision to remove Edgardo Mortara.

However, this contemporary debate has overlooked the fact that the question of Aquinas's teaching on forced baptism was at the center of a rather extensive theological exchange between the Mortara family, and the Vatican's papal counsel in 1858. Soon after Edgardo was abducted, the Mortara family, with the assistance of the Jewish community in Rome, submitted a formal document that argued that the child must be returned because the Church, according to Aquinas, prohibits baptizing children of unbelievers without the consent of their parents. The Mortara family's document appealed to the same teachings in Aquinas cited by critics of Cessario. Yet the papal counsel's refutation also appealed to Aquinas's teaching in order to defend the decision to separate Edgardo from his parents. That Aquinas's teaching is cited as the authority for, and against, the return of Edgardo to his family in the 1858 exchange, and on both sides of the contemporary debate, raises questions about the interpretation of Aquinas's teaching on forced baptism as it relates to the Mortara affair. How do the authors of the Mortara and Vatican documents interpret Aquinas's teaching against forced baptism? What were the key questions on forced baptism as these related to Aquinas's teaching? How do scholars in the contemporary discussion understand Aquinas's teaching to apply to the Mortara case? This essay attempts to clarify the key questions on Aquinas's teaching in the debate between the Mortara family, and the papal counsel. Without attention to the 1858 exchange, the contemporary debate lacks an understanding of the questions in the dispute as these relate to Aquinas's theology, as well as the significance of Aquinas's teaching against forced baptism of Jewish children. I hope to show that identification of these questions is a helpful first step in evaluating the significance of Aquinas's teaching for the contemporary discussion.

The essay is organized in three parts. First, I analyze the arguments of the Mortara family's plea, and the papal counsel's reply, with attention to how the authors of the documents interpret Aquinas's teaching against forced baptism. How are Aquinas's texts used in the arguments for, and against, Pius IX's decision? I argue that two key questions were at the heart of the dispute: the question of licit or lawful baptism, and the question of valid baptism. In the second part of the essay, I examine use of Aquinas in contemporary arguments about the Mortara affair. The

\footnotetext{
${ }^{4}$ Eléna Mortara, the great-granddaughter of Edgardo's older sister, said that Edgardo's kidnapping has always been an open wound for the family. Anna Momigliano, "Why Some Catholics Still Defend the Kidnapping of Edgardo Mortara," January 24, 2018, https://www.theatlantic.com/international/archive/2018/01/some-catholics-are-defending-the-kidnapping-of-a-jewish-boy/551240/.

${ }^{5}$ Nathaniel Peters, "Grace Builds Upon and Doesn't Destroy Nature: On First Things, Baptism, and the Natural Family," Public Discourse, January 15, 2018, http://www.thepublicdiscourse.com/2018/01/20884/. I discuss the other scholars who appealed to Aquinas below.
} 
essay details how contemporary thinkers employ Aquinas's texts in their arguments, and what questions they understand as central to the discussion. I then show that the contemporary discussion could benefit from a close examination of Aquinas's teaching as interpreted by both sides of the 1858 dispute. Finally, I discuss two eighteenth-century cases in which Roman Jews appealed to Aquinas's teaching to defend their parental rights. I conclude with a brief summary of Aquinas's argument against forced baptism of Jewish children.

\section{Aquinas in the Mortara's Syllabus and Papal Counsel's Reply}

Soon after Edgardo was abducted, the Mortara family submitted a two-part document to the Holy See, Pro-memoria e sillabo (referred to hereafter as Promemoria and Syllabus). The document, which cited numerous theologians, including Aquinas, set forth theological and legal arguments for the return of Edgardo Mortara. ${ }^{6}$ However, the papal counsel's refutation of the Mortara family's document, entitled Brevi cenni e reflessioni (referred to hereafter as Brevi cenni), also appealed to Aquinas in order to defend Pius's decision to remove Edgardo from his parents. ${ }^{7}$ In this section, I analyze the arguments of the Pro memoria and Syllabus, and Brevi cenni, with attention to how the authors of the documents interpret Aquinas's teaching against forced baptism. I show that two questions were at the heart of the dispute between the parties: the question of licit or lawful baptism, and the question of valid baptism.

The Pro-memoria and Syllabus was written with the assistance of the Jewish community in Rome, which had become familiar with canon law. ${ }^{8}$ The eight-page section, entitled, Pro-memoria functioned as an introduction to the major fifty-page section of the document, the Syllabus, which sought to persuade the Vatican to release Mortara. With the exception of a few parts of the Pro-memoria, the entire document is written in Latin. Rabbis among the Roman Jewish community assembled and included antecedent cases of forced baptism that involved Jewish families. These cases were then organized along with the largest part of the document, the Syllabus, which citied theologians and canon lawyers as authorities. "To persuade the Church to release Edgardo, they believed, it was necessary to show that ecclesiastical law and precedent were on their side, and this could be done only by

\footnotetext{
${ }^{6}$ I rely on the dissertation analyzing these documents written by Sharon Stahl, The Mortara Affair, 1858: Reflections of the Struggle to Maintain the Temporal Power of the Papacy. Saint Louis University (ProQuest Dissertations Publishing, 1987). The Mortara document and the Vatican reply are part of the archives of the pontificate of Pius IX, which were released in 1967, and housed in the Vatican Archives. Pro-memoria e sillabo may be found in Fondo Pio IX, oggetti vari, n. 1433, "Mortara Edgardo"; and Brevi cenni e reflessioni in the files of the Secretary of State. See Segretario di Stato, Anno 1864, rubrica 66 (Ebrei), Fascile 1, 2, 3 .

${ }^{7}$ Brevi cenni e reflessioni is an abbreviated title for "A brief explanation and reflections on the promemoria and syllabus humbly presented to His Holiness, Pope Pius IX, concerning the baptism confirmed in Bologna on the child Edgardo, son of the Jews Salomone and Marianna Mortara." Brevi cenni was distributed to papal nuncios, church representatives, and friends of the Church throughout Europe who were requesting that the Vatican help them mount a more effective defense of Pius IX's actions. Kertzer, 146.

${ }^{8}$ The name of the author (or authors) of the plea is unknown.
} 
experts in ecclesiastical law and Church history." 9 In addition to the citation of Church authorities, the Mortara family's plea included three appendices: Edgardo's birth certificate; a medical report certifying that Edgardo's illness at the time of his baptism was not life-threatening; and the text of a 1639 Church decision in a case of forced baptism.

The main argument of the document is that the child must be returned because the Church, according to Aquinas, does not allow children of unbelievers to be baptized without the consent of their parents. "With almost talmudic logic, the work argued that...that since the Church does not allow the children of 'infidels' to be baptized without parental approval, Edgardo should be returned to his family. And it relied heavily on the teachings of medieval scholar and Dominican priest Saint Thomas Aquinas." ${ }^{10}$ Within three months of Edgardo's kidnapping, the Jewish community of Rome had produced a rather extensive theological argument against forced baptism of Jewish children, with Aquinas as the "major authority." 11 As Kertzer observes, "The star witness in the Syllabus, was Thomas Aquinas, who argued that a son should be considered a part of his father and under his authority." 12 Indeed, the document written by the Mortara family's counsel appealed to the same teachings in the Summa theologiae cited by contemporary critics of Cessario's article. The Mortara family's Syllabus then sought to reinforce Aquinas's arguments against forced conversion of Jewish children with numerous citations of Dominican theologians, and canon lawyers. The document also cites scholars who base their arguments against baptism invitus parentibus (without the consent or against the wishes of the parents) on Aquinas's writings.

Four main arguments are first introduced in the Pro-memoria, and then followed by citations of canon lawyers and theologians throughout the fifty-page Syllabus..$^{13}$ The arguments can be summarized as follows: 1) It is not the custom of the Church to baptize children of unbelievers invitus parentibus; 2) the Church has no authority over the children of unbelievers; and 3) the baptisms of infidel children invitus parentibus, are invalid. ${ }^{14}$ In this section, I do not examine the texts of Aquinas cited by the authors of the Syllabus. I only indicate where themes in the Syllabus correspond to Aquinas's texts. ${ }^{15}$

For the first argument, the document appeals to all three of the places in Aquinas's corpus in which he treats the topic of forced baptism: Summa theologiae IIII 10.12; III 68.10; Quodlibetales Questiones 2.4.2. ${ }^{16}$ The texts are used to argue

\footnotetext{
${ }^{9}$ Stahl, 1. Kertzer, Kidnapping, 145.

${ }^{10}$ Netty C. Gross, "Baptism by Force," Jerusalem Post, January 7, 1994.

${ }^{11}$ Stahl, 47.

${ }^{12}$ Kertzer, Kidnapping, 144. Kertzer echoes the observation first made by Stahl.

${ }^{13}$ The document is organized based on author, and does not list the arguments in order. Stahl, 46.

${ }^{13}$ Stahl, 47.

${ }^{14}$ Stahl, 47.

${ }^{15}$ I will say more about Aquinas's arguments against forced baptism of Jewish children near the end of section three.

${ }^{16}$ Stahl, 49. Citations of Thomas Aquinas in the Latin are from Leonine Opera omnia: Opera omnia iussu impensaque Leonis XIII. P.M. edita (Rome 1882). English translations are based on the Benziger edition of the Summa Theologica unless otherwise indicated. Summa Theologica, trans. Fathers of the
} 
that according to the natural law, a child is under the care of the parents before it has the use of reason. ${ }^{17}$ Support for Aquinas's position is then reinforced with appeals to the following theologians: the French Dominican theologian, John Capreolus (1380-1444); the Dominican Cardinal Juan de Torquemada (13881468); the French Dominican theologian, Durandus of Saint-Pourçain (12701334); the French Dominican theologian, and Patriarch of Jerusalem, Pierre de La Paludanus (1275-1342); the Italian physician and scholar Marsilius of Padua (1275-1342); and the Italian Dominican theologian, and canon lawyer, Ambrosius Catherinus (1484-1553). ${ }^{18}$

The possibility that the forcibly baptized would later leave the faith is also stressed by a number of these theologians cited by the Mortara family. "For when the baptized child came to adulthood he could easily move away from that which he had done out of ignorance, against the will of those who had care over him." 19 The Syllabus argues that: "an 'infidel child' will not likely be encouraged in the new faith by the infidel parents, and so would abandon the faith and commit apostasy." 20 This problem was originally addressed in Canon 57 of Toledo IV. ${ }^{21}$ The longstanding concern is mentioned by Aquinas in II.II 10.12 as one reason for the custom not to baptize children of unbelievers against the will of their parents. The

English Dominican Province (New York, 1947). Citations of the Summa will appear in the text and notes as: II.II 10.8 ad. 1. "II.II" stands for Secunda Secundae, or part two of the second part of the Summa, and "III" stands for the Tertia Pars or third part of the Summa; "10" stands for question 10; and " 8 " for the article; "obj." stands for an objection in an article; and "ad." for reply objection.

${ }^{17}$ In II.II 10.12, Aquinas argues baptizing children of unbelievers invitus parentibus "is against natural justice. For a child is by nature part of its father: thus, at first, it is not distinct from its parents as to its body, so long as it is enfolded within its mother's womb; and later on after birth, and before it has the use of its free-will, it is enfolded in the care of its parents, which is like a spiritual womb...."

${ }^{18}$ John Capreolus, known as "prince of Thomists," was a Dominican, who lectured at Paris and Toulouse. A native of Languedoc, he entered the Dominican Order at Rodez, and was Regent of Studies at Toulouse. His main work was a defense of the teaching of Aquinas against numerous attacks of Henry of Ghent, Duns Scotus, Durandus of St-Pourçain, William of Ockham, and others. See Weisheipl, J. A., "Capreolus, John," New Catholic Encyclopedia, 2nd ed., vol. 3 (Gale, 2003), 92-93. Juan de Torquemada was a Spanish theologian who entered the Dominican Order in 1404. He was a Dominican cardinal, "illustrious theologian, defender of papal authority against the conciliarists at Basel." Courtney, F. "Torquemada, Juan de." New Catholic Encyclopedia, 2nd ed., vol. 14 (Gale, 2003), 112-113. Durandus of Saint-Pourçain was a Dominican bishop and scholastic theologian. He was one of the earliest exponents of what came to be called Nominalism, which he developed in directions distinct from the teaching of St Thomas Aquinas. He was censured by a theological commission appointed by the Dominican Master General. Weisheipl, J. A., "Durandus of Saint-Pourçain." New Catholic Encyclopedia, 2nd ed., vol. 4, (Gale, 2003), 947-949; Peter Paludanus was a French Dominican and became Patriarch of Jerusalem in 1329. Paludanus wrote a concordance to Aquinas's Summa theologiae. Stahl, 52; See Jean Dunbabin, A Hound of God: Pierre de La Palud and the Fourteenth-Century Church (Oxford University Press, 1991). Marsilius of Padua, well known for his Defender of the Peace, is often considered a forerunner of the Reformers, and modern democracy. The Italian Dominican theologian and canon lawyer, Ambrosius Catherinus was appointed bishop of Minori in 1546; he was made archbishop of Conza in 1552. Cooney, J. R. "Ambrosius Catharinus (Lancelot Politi)," New Catholic Encyclopedia, 2nd ed., vol. 1 (Gale, 2003), 347.

${ }^{19}$ Stahl, 52-3.

${ }^{20}$ Stahl, 47.

${ }^{21}$ Amnon Linder, The Jews in the Legal Sources of the Early Middle Ages (Wayne State University Press, 1997), 486. 
first argument set forth by the Mortara's therefore corresponds directly to a reason listed in Aquinas's article on the topic in II.II 10.12. ${ }^{22}$

The second argument of the Mortara's document is that unbelievers are not subject to the jurisdiction of the Church in spiritual matters since they reside outside the Church. ${ }^{23}$ The argument resembles Aquinas's teaching in II.II 10.9 ad. 2 on this point. ${ }^{24}$

The third argument in the Mortara's plea addresses additional reasons why children may not be baptized without consent of their parents, including the necessity of intent, the authority to baptize, and the circumstances of impending death. The argument is that baptism of a child invitus parentibus is invalid since the implied will of a small child before the use of reason is the will of his parents. ${ }^{25}$ "Therefore, if without parental consent a child would be baptized, nothing takes place since there is absent either a direct or an implied will." 26

Stahl observes that there are four corollaries to this point on valid baptism: 1) forced baptisms are invalid; 2) there must be intent on the part of the baptized, not simply the lack of an impediment, which would be the case in the baptism of an infant; 3) a qualified person must administer the rite of baptism; and 4) even the circumstances of imminent death does not negate the accepted custom of the Church that an infidel child may not be baptized without the permission of his parents. $^{27}$

Regarding the necessity of intention of the recipient, several of these Dominicans interpret Aquinas to teach that a forced baptism is an invalid baptism precisely because it lacks intent.

For the reception of this kind of sacrament, namely baptism, there is required the intention or the will of the one who receives it, the intention or will that is proper or implicit. But in the case of a small son of infidel parents, if such a child would be baptized without parental consent there is no proper will of receiving the sacrament, as is obvious, nor is there an implicit one since he would be baptized without parental consent. Whose will is the will of the child? Therefore, if it is done in such a way, no baptism would take place. ${ }^{28}$

\footnotetext{
${ }^{22}$ II.II 10.12: "Children baptized before they have the use of reason, afterwards when they come to perfect age, might easily be persuaded by their parents to renounce what they had unknowingly embraced; and this would be detrimental to the faith."

${ }^{23}$ Stahl, 59-62.

${ }^{24}$ II.II 10.9 ad. 2: "The Church does not exercise judgment against unbelievers in the point of inflicting spiritual punishment on them...."

${ }^{25}$ Stahl, 63.

${ }^{26}$ Stahl, 50-51.

${ }^{27}$ Stahl, 63.

${ }^{28}$ Durandus cited in Stahl, 64; 66-67.
} 
Torquemada is also cited on this point, using similar language: "Children in those matters which are part of the divine law either require a true act of the will or an implied act of the will nor ought this to be done, nor if done is it valid." 29

The Mortara family's document then addresses the forced baptisms in cases of impending death, and those who would argue that in such a case, an infidel child must be baptized invitus parentibus. Appealing to Paludanus, the document states that even when an infidel child is in danger of death, a Christian still has no right or power of the child. To act as if one had power or care over the child would violate natural and divine law. In an argument that repeats and extends aspects of Aquinas's rejection (in II.II 10.12 ad. 2) of the theological argument that baptizing an infant invitus parentibus is justified in order to save the child's immortal soul Paludanus writes,

And if it should be argued against the things which have been said that help is much more to be extended to the danger of eternal death than temporal death but that a child who exists in danger of temporal death is to be aided even against the will of his parents, especially if they wish the contrary out of malice, therefore all the more must help be given to the children of infidels against the danger of eternal death, even when their parents are unwilling. But it has been well replied that help is not to be extended to anyone in corporal danger contrary to the ordinances of the civil law. Wherefore, if anyone would be condemned to death, rightfully by a judge, he ought not to be rescued violently. In a similar way, against the ordinance of the natural and the divine law, that the son who is under the care of the parent must not be taken from them so as to be freed from the danger of eternal death, for evil must not be done that good may come about. But this would be the case if an infidel's son would be removed from his parents to whose care he is subordinated as far as the natural and divine law is concerned. Because just as proper water ought not to be taken from someone unwillingly in order to baptize a child, if that one was not willing to give it freely, nor on behalf of money, because this is against justice, so neither ought a child to be removed from his parents for the sake of baptism. .... $^{30}$

\footnotetext{
${ }^{29}$ Stahl, 68. Durandus elaborates on this point, which Stahl summarizes: "In the case of a child, there must be an implied will, which would be the will of the parents. In the case of infidel parents, however, there is no implied will since the parents do not wish the child to be baptized. And since the will of the father is the will of the child, a baptism of an infidel child would be invalid since there is no intent through the implied will of the parent who is responsible for the child." "...[I]f such a child were in fact baptized there is no baptism. This is less obvious of itself but is proved all the more because if an adult were raised in such a way that he had heard nothing about the faith and if he were only in original sin, if such a person were sleeping and while sleeping was baptized, it is evident that there is no such baptism, not because baptism finds in his will more of a bar than in the case of the small child because there would be absent the will or intention of receiving baptism. Therefore for the reception of baptism is required a personal will of the one receiving it if it is an adult or an implied will if it is a child, and this case was the major one, therefore the conclusion follows." Stahl, 69-70.

${ }^{30}$ Cited in Stahl, 72. I return to Aquinas's handling of this issue below.
} 
Finally, some of the authorities cited in the Mortara Syllabus are also concerned with misinterpretations of Aquinas's teaching against baptism invitus parentibus. Stahl thinks the function of Italian Dominican theologian and canon lawyer, Catherinus, in the Mortara document, is "to destroy the arguments of those who would interpret Thomas to allow the baptism of infidel children, and to repudiate those theologians in the Church who have offered their own contrary opinion son this matter." ${ }^{31}$ In Catherinus's view, foremost among the misinterpreters of Aquinas on forced baptism, is Cardinal Cajetan. Catherinus writes,

...I cannot cease being amazed at this contrary teaching of Cajetanus that anyone can be baptized against his will. For these children must be thought not to have given consent since their parents have not given consent, whose will is thought to be the will of the children? For just as if the parents' consent, the child is understood to have consented so similarly the dissent of the children. And let no one say to me if the parents are unwilling, nonetheless, consent and faith can be provided to the children by the Church and the officials of the Church as we say in the case of Christian infants if perchance their Christian parents forbid their baptism. ${ }^{32}$

"One must conclude," writes Catherinus, "that without the will of the parents the children of Jews or of any infidels existing outside of the Church cannot be baptized, nor if they are baptized is the baptism valid." 33

The papal counsel's response to the Mortara family's plea consisted of a thirtyfour-page document, Brevi cenni, which attempts to refute the Syllabus. ${ }^{34}$ The papal counsel lists the Mortara's assertions, which it counted as five. ${ }^{35}$

1) The newborn children of Jews neither can nor should be baptized against the wishes of their parents.

2) In cases where children, before the age of reason, are baptized invitus parentibus, the baptism is invalid.

3) Even if it supposed that such a baptism is valid, the parents still have authority over the child by natural law, and if their child has been taken from them they have every right to demand he be returned.

4) That in the case in question, there is insufficient proof that the maid-servant Anna Morisi performed the rite of baptism on the child Edgardo Mortara.

5) Because of the above reasons, the Mortaras claim the return of their son Edgardo.

\footnotetext{
${ }^{31}$ Stahl, 57.

${ }^{32}$ Cited in Stahl, 57.

${ }^{33}$ Cited in Stahl, 65.

34 "Brevi cenni e riflessioni sul Pro-memoria," cited in Stahl, "The Mortara Affair, 1858."

${ }^{35}$ Stahl, 91.
} 
Then the papal counsel lists its own positions, which respond directly to what it understands as the Mortara's five arguments. ${ }^{36}$

1) The first assertion of the Mortaras is true but it does not influence the case in question.

2) The second assertion is, "reckless, false, contrary to the judgements of all the canonists and theologians, and in opposition to the steadfast observances of the universal Church, and already condemned by the Holy See in many decisions."

3) The right that the Church has over baptized children prevails over the rights of the parents. Moreover, the Church must keep the child, and see to his education in the faith.

4) In the case in question the Church has the full canonical proof of the conferred baptism to the child Edgardo Mortara by the maids-servant Anna Morisi and therefore there is no reason nor right to restore the child to parental authority.

5) The Church does not accept the claim of the Mortara parents to their child.

The counsel agrees with part of the Mortara's first point when it states that the Church has always been against forced conversions. But a baptism, even if illicit, is still valid, and failing to distinguish these two things is the weakness in the Mortara position. ${ }^{37}$ As Kertzer observes, "... though the Church could be shown to oppose these forced baptisms, does it necessarily follow that no baptismal ceremony performed on Edgardo could have been valid? Here the question was more complicated." ${ }^{38}$ The papal counsel's main argument is that a baptism administered against the will of the parents (illicit) is nevertheless a valid baptism: "In fact all the theologians and canonists demonstrate the validity of such baptism exclusive of the consent of the interpretive will of the parents." 39

The papal counsel then says this is why Aquinas advises that the children of unbelievers may not be baptized without their parents' consent. In the papal counsel's view, according to Aquinas, if they are baptized it is valid and they are then the responsibility of the Church. ${ }^{40}$

The Angelic Doctor, while he shows with judgements and authority that Jewish children should not be baptized against the wishes of their parents, demonstrates, as equally in the places cited in the Pro-memoria and in the Syllabus, that if there should be baptisms conferred to such children, that baptism

\footnotetext{
${ }^{36}$ Stahl, 91-2.

${ }^{37}$ Stahl argues that rejection of the Mortara's request to return Edgardo was based on political concerns about the loss of power due to the unification of Italy, and not simply adherence to canon law. Stahl, 1-2.

${ }^{38}$ Kertzer, Kidnapping, 145.

${ }^{39}$ Stahl, 97.

${ }^{40}$ Stahl, 97.
} 
is confirmed and valid, and that for this reason these sons should not be left in the power of the parents is more certain than certain...."41

The interpretation of Aquinas in the exchange between the Mortara family and the papal counsel concerned two key questions. The first is whether Aquinas holds that forced baptism is lawful or licit. The Mortaras argued that Aquinas was against baptizing children without the consent of parents. The papal counsel agreed but claimed this point is irrelevant to the case because Edgardo had already received a valid baptism. Another question is also important to the issue of licit baptisms: does Aquinas teach that baptism of Jewish children invitus parentibus is lawful in certain exceptions, such as in the case of an infant in danger of death? The second key question that emerges in the exchange between the Mortara family and the papal counsel is whether forced baptism of a child of unbelievers is nevertheless a valid baptism. According to the papal counsel, Aquinas thinks such a baptism is valid.

\section{Aquinas in the Contemporary Discussion of the Mortara Affair}

Romanus Cessario's argument is that an accurate understanding of the Catholic teaching on baptism allows one to see that Pius IX's decision was not only just but an important act of piety, and strength: "In order to forestall wrong and unwarranted interpretations, which may include allusions to child abuse, Catholics and other people of good will must acquire a right understanding of baptism and its effects." ${ }^{22}$ In Cessario's view, one must look beyond the human pathos of the case to see that what was required by the law of the Church, and the Papal States, concerned the deeper realities of the power and permanence of baptism, and the logical, political consequences of receiving this sacrament. In the light of this deeper theology of baptism, one can see that the removal of Mortara was not a kidnapping at all; it was a relocation of an immortal soul into the Christian life, kindly arranged by divine Providence. ${ }^{43}$

Cessario's argument is as follows:

1) An infant in danger of death can be baptized licitly even against the will of non-Catholic parents. Cessario cites the 1983 Codex iuris canonici 868, and explains that $\S 2$ affirms that "an infant of Catholic parents or even of nonCatholic parents is baptized licitly in danger of death even against the will of their parents." 44

2) Baptism seals a person with an indelible spiritual mark that configures a person to Christ.

\footnotetext{
${ }^{41}$ Stahl, 100. The papal counsel likely has in mind the sed contra of II-II q. 10 a. 12: "[Jews] would lose the rights of parental authority over their children as soon as these were Christians." I discuss this text below.

${ }_{42}^{42}$ Cessario, 56.

${ }^{43}$ Cessario, 56.

${ }^{44}$ Codex Iuris Canonici (Vatican City 1983); Cessario, 56.
} 
3) The law of the Church and the civil law of the Papal States require that legitimately baptized children receive a Catholic education (expressed today in Codex iuris canonici 868 § 2). ${ }^{45}$

4) Therefore, Pius IX was right to relocate Edgardo from his family and provide him with a Catholic education.

Cessario appeals to Aquinas's theology of baptism in the second premise of his argument; on the point that baptism is indelible. ${ }^{46}$ For Cessario, baptism of an infant against the will of the parents is lawful and efficacious, and if civil law mandated Catholic children to be raised by Catholics, then it seems to follow that the relocation of Edgardo is not an affront to religious liberty but, especially given the difficulty of the situation, and the political pressure faced by Pius IX, a courageous commitment to the Church's teaching on the efficacy of baptism. At the end of the day, it was faith that bound Pius to give Mortara a Catholic upbringing that his parents could not. To misunderstand these divine sacramental realities is to leave oneself open to the danger of accommodation to modern liberalism, and anti-Catholic sentiment. If one conceives of the Mortara case as a kidnapping, one has fallen victim to modern indifference to theological claims, and perhaps anti-Catholic prejudice. ${ }^{47}$

Cessario thinks the more important issue is that the Mortara affair highlights a theological concern that Jewish and Christian communities share: "Jews and Christians alike pledge a higher loyalty that they honor in ways that seem incomprehensible to the world. It is a secularist denial of those higher loyalties that threatens both synagogues and Church." 48

Several Catholic thinkers also emphasize human vs. supernatural elements of the case, insisting that a materialistic view prevents one from seeing the sound theological reasoning behind the decision to remove Edgardo. In the postscript to his The Unpublished Memoirs of Edgardo Mortara, the Italian Church historian, Vittorio Messori, examines Mortara's personal archive, and defends the abduction. ${ }^{49}$ Catholic theologian Roy Schoeman, claims the case "sits at crossroads of the greatest social transformation of modern times: from a fundamentally religious view of the world to a fundamentally materialistic one. Those two views can lead to diametrically opposed conclusions about the Mortara case. ${ }^{\prime 50}$ For these authors, the

\footnotetext{
${ }^{45}$ Cessario, 55.

${ }^{46}$ Cessario does not cite to a text in Aquinas but likely has Aquinas's treatment of baptism in mind, which Aquinas includes in the Tertia Pars of the Summa theologiae.

${ }^{47}$ Cessario, 56. In Cessario's view, the Mortara case exacerbated anti-Catholic sentiment in the United States, and the upcoming film proves that prejudiced manipulation of the Mortara case has not disappeared. Cessario's view seems to echo themes in the American Catholic reaction to the controversy in 1858, which emphasized that those critical of Pius IX were motivated by anti-Catholic prejudice. Bertram Wallace Korn, The American Reaction to the Mortara Case: 1858-1859 (American Jewish Archives, 1957).

${ }^{48}$ Cessario, 58.

${ }^{49}$ Messori, 1.

${ }^{50}$ Schoeman, Foreword to Messori, vii. Anna Momigliano observes that both Cessario and Messori are "making a larger theological argument - about divine doctrine trumping human morality, and about religion taking precedence over civil rights. Both Cessario and Messori are quite explicit about this...
} 
morality of Pius IX's actions in the Mortara affair are viewed differently based on whether one accepts the truth of the Catholic faith: "In the light of the faith, what the pope did can be seen as not only legally justified but also morally justified; in the darkness of a total rejection of the faith, it appears unconscionable." ${ }^{51}$

Several scholars and writers denounced Cessario's essay, and briefly mentioned what they understood as the theological issues raised by the case. Massimo Faggioli criticized Cessario's essay as an example of a Catholic traditionalism that ignores the Second Vatican Council's teaching on the Jewish people, religious liberty, and freedom of conscience. ${ }^{52}$ Rod Dreher called Cessario's essay shocking, monstrous, and grotesque. "They stole a child from his mother and father! And here, in the 21st century, a priest defends it, saying it was for the child's own good. " ${ }^{53}$ Dreher claimed Cessario's position is wrong, and asserted that the Mortara case is a challenging question, "because Christians really do believe that baptism is a permanent thing. We really do believe that Christianity is objectively true."

However, the scholars that cited Aquinas's teachings in their response are our main concern. Princeton University Professor Robert George called the piece an embarrassment, and cited Aquinas's teaching: "The taking of the child by force from his parents and family was an abomination and defending it is an embarrassment. The gross, unspeakable injustice of such an action (and of its predicate, namely, baptizing a child against the will of its parents) was well understood by the early and medieval church and was affirmed and explained by Aquinas. Christians, including popes, can commit, and sometimes have committed, profoundly unChristian acts-and can, and have, committed them in the name of Christianity. This, shamefully, was such a case. ${ }^{" 54}$ Michael Sean Winters charged that Cessario makes "suspect claims based on a sectarian theological point." ${ }^{55} \mathrm{He}$ argued that Cessario is using a theological principle about grace and baptism to overturn other principles such as the election of Israel, mercy, the importance of Catholic-Jewish relations, and the teaching of John Paul II. Cessario's piece also represents a failure to recognize and respect human dignity: "Only a failure to recognize the human dignity of our Jewish brothers and sisters can account for the crime then, or for

\footnotetext{
In his book, Messori makes a similar point, encouraging a return to a Katholischeweltanschauung, or Catholic worldview, in which the salvation of the soul is deemed more important than other concerns." Momigliano, "Why Some Catholics Still Defend the Kidnapping."

${ }^{51}$ Schoeman, Foreword to Messori, ix.

52 "Cessario's First Things article is an example of the extremism on the side of continuity: it ignores completely the development of Catholic teaching on Jews and Judaism, on religious liberty, and on the freedom of conscience approved by Vatican II, confirmed and repeated by all the popes of the postVatican II period. It assumes that the Catholic magisterial tradition that followed and changed nineteenth-century Catholicism is not authentic Catholic teaching." Massimo Faggioli, "Obsessed with Continuity: What an Essay on the Mortara Kidnapping Confirms," Commonweal January 20, 2018, https://www.commonwealmagazine.org/obsessed-continuity

53 Rod Dreher, "The Edgardo Mortara Case," The American Conservative, January 9, 2018, http://www.theamericanconservative.com/dreher/the-edgardo-mortara-case/.

${ }^{54}$ Robert George's comments were cited in Dreher's piece.

${ }^{55}$ Michael Sean Winters, "Fr. Cessario's Edgardo Mortara Essay Is Inexcusable," National Catholic Reporter, January 19, 2018, https://www.ncronline.org/news/people/distinctly-catholic/fr-cessarios-edgardo-mortara-essay-inexcusable.
} 
Cessario's attempts to excuse it now." Winters said that Cessario's argument is based in Aquinas's teachings: “...[Cessario's] whole argument is premised on certain Thomistic understandings of how grace must work." 56

A few scholars elaborated upon Aquinas's teaching. Nathaniel Peters argued that although Cessario extensively quotes Aquinas on the indelible character of baptism, he "passes over Aquinas's treatment of who should receive baptism." ${ }^{57}$ Peters then cites one of the places in the Summa that Aquinas takes up the question. ${ }^{58} \mathrm{He}$ cites Aquinas's argument that children who do not yet have free will are under the care of their parents according to the natural law. And he shows that in his reply to the objections given, Aquinas makes clear that the natural order ordained by God binds children to the care of their parents. Peters argues that for "all the importance of the sacraments, they cannot become an excuse for violating natural justice." Additionally, Peters also cites II.II 10.12 and argues that Aquinas's reply to objection 3 of article 12 shows that Aquinas thinks that even though Christian kings and princes may have civil power over Jews and other unbelievers it does not follow that they have power to overthrow the order of natural or divine law.

Holly Taylor Coolman thinks Cessario's argument is "deeply damaging and misguided." ${ }^{59}$ Coolman's response aimed to identify pertinent theological questions raised by the case, with attention to the need for dialogue: "... substantive engagement with the material issues is the very thing we need most." According to Coolman, the first issue the Mortara affair raises is that of nature and grace. Coolman argued that Aquinas's dictum that grace does not destroy but rather perfects nature implies that the natural bond between parent and child must not be destroyed even for the highest good. Coolman argued that Aquinas applied this principle when he argued in II.II 10.12 that baptisms of Jewish children against the wishes of the parents are unjust. In Coolman's view, the Mortara case also raises the question of the relationship between Church and state, and questions related to Nostra Aetae.

Finally, Robert Miller argued Cessario's piece is "statist" and sets aside the theological questions concerning baptism. ${ }^{60}$ Miller gives Cessario the benefit of the doubt that the baptism was lawful and licit. Simply because the baptism is licit, it does not follow that the state has a right to remove a child from their parents simply because a child is Catholic: "Cessario has shown that, assuming the truth of the Catholic faith, Mortara had a supernatural, theological right to a Catholic upbringing and education, with a correlative duty in the Church (particularly the pope), to provide him one. That may well be so, but a moral claim (much less a supernatural

\footnotetext{
${ }^{56}$ Ibid.

${ }^{57}$ Peters, "Grace Builds Upon and Doesn't Destroy Nature."

${ }^{58}$ III 68.10

${ }^{59}$ Holly Taylor Coolman, "The Vatican kidnapped a Jewish Boy in 1858. Why are we still talking about it?" America, January 31, 2018, https://www.americamagazine.org/faith/2018/01/31/vatican-kidnapped-jewish-boy-1858-why-are-we-still-talking-about-it

${ }^{60}$ Robert Miller, "The Mortara Case and the Limits of State Power: First Things Should Disavow Fr. Cessario's Defense of Pius IX in the Mortara Case," Public Discourse, January 11, 2018, http://www.thepublicdiscourse.com/2018/01/20868/.
} 
moral claim) does not, without more, support a moral right in the state to enforce that claim."

In the light of the 1858 exchange, we can see that the question of Aquinas's teaching on forced baptism is more complex than perhaps has been realized. The contemporary discussion of the Mortara Affair has overlooked difficulties in Aquinas. Cessario nor his critics have addressed whether Aquinas's teaching considers baptism of an infant near death as a lawful baptism. As we can see from the analysis of the Mortara family document, this is one of the questions in the 1858 exchange. Additionally, contemporary critics of Cessario have not addressed the text cited by the papal counsel that seems to indicate Aquinas thinks children should be removed from their parents if they have been baptized: "Now it would be an injustice to Jews if their children were to be baptized against their will, since they would lose the rights of parental authority over their children as soon as these were Christians." ${ }^{61}$ Does Aquinas teach that a forced baptism is nevertheless valid or the corollary idea that Jewish parents lose their rights over their children if they are baptized?

\section{Roman Jewish Appeals to Aquinas's Teaching Against Forced Baptism}

The Mortaras were not the first Jewish family to appeal to Aquinas's teaching in defense of kidnappings of their children. According to Kertzer, "Italy's Jews had become, by sad necessity, expert in canon law on matters affecting them, and especially on the question of forced baptism, the major communities regularly exchanged documents." ${ }^{62}$ The Jews of the Roman Jewish Ghetto appealed to Aquinas's teaching in at least two other cases.

Before the Mortara affair, Roman Jewish children and adults were abducted from the Roman Ghetto and/or coerced into baptism through a variety of means, including "offerings," which were based on the legal principle, favor fidei (the priority of the faith) ${ }^{63}$ Roman Jewish responses to these forced baptisms sometimes

\footnotetext{
${ }^{61}$ II-II 10.12

${ }^{62}$ Kertzer, Kidnapping, 144.

${ }^{63}$ Benedict XIV (r. 1740-1758) added a list of exceptions to the Church's customary prohibition on forced baptism of Jews based on two hypothetical cases: a Christian who finds a Jewish baby in danger of death; and a Jewish child found alone in the city outside the ghetto. Regarding danger of death exception, Benedict said such baptisms were "without a doubt a praiseworthy and meritorious thing." Ambiguity concerning what constituted danger of death meant that the decision was made by the Christian doing the baptizing. Regarding a child found alone, or abandonment, the Pope ruled that although Jews enjoy patria potestas (power of a father, or parental rights) over their children, such rights are lost in cases of abandonment. Other exceptions state that Jewish children could be baptized in the following circumstances: if the Jewish parents were absent, and their guardians consented; if the Jewish father commanded it, even if the mother were unwilling; or if a Jewish convert to Christianity made offering of a Jewish family member to the Church. Benedict ruled that Jewish converts had the right to offer their relatives on the basis of the legal principle, favor fidei (the priority of the faith). According to Kenneth Stow, favor fidei was an umbrella principle that expressed the idea of the good of Church and state; it protected a wide array of legal and theological needs. The principle had enormous legal force. Kenneth R. Stow, "The Cruel Jewish Father: From Miracle to Murder," Studies in Medieval Jewish Intellectual and Social History: Festschrift in Honor of Robert Chazan, ed. David Engel, Lawrence H. Schiffman, Eliot R. Wolfson (Leiden: Brill, 2012), 245-278; See Marina Caffiero, Forced
} 
included formal legal pleas submitted to the Vatican. In 1713, Mazaldo Cohen, the three-and-a-half-year-old daughter of Sara Cohen was taken to the House of Catechumens for conversion by Sara's brother-in-law, Israel Jona, who had himself converted. Sara appealed to the Congregation with the support of a Christian lawyer, Francesco Maria Spannocchi. ${ }^{64}$ Spannocchi argued to the Congregation that Aquinas prohibited the baptism of small children invitus parentibus, which Spannocchi claimed covered both father and mother. The petition argued for the mother's guardianship, and claimed that her brother-in-law had simply kidnapped her daughter. The rector of the House of Catechumens, Don Crisante Cozzi, argued that the child was not kidnapped but came to convert by divine will since the child had made the sign of the Cross. ${ }^{65}$ The final decision was against the mother, Sara Cohen. After two months of separation from her daughter, Sara asked to be baptized at the House of Catechumens.

In another case, in 1762, Stella, who was three, and Ester, who was six, were taken from their Jewish parents because they had been offered by their Jewish grandmother, who had converted. The grandmother also offered the unborn child of the pregnant daughter-in-law, Allegrezza, who publicly opposed the offering. The six-year-old and three-year-old were taken by force from their parents' arms in middle of the night. Their defense was handled by a Roman lawyer, Carlo Luti, who represented Jews in defense of parental rights cases. Luti also appealed to Aquinas: "As could be expected, the petition cited the authority of St. Thomas and the canonists who prohibited the baptism of children without the consent of the parents." ${ }^{66}$ The plea was denied, however, on the basis of concern for the soul of the infant, and what the counsel regarded as failure of parents to guide him: “...when those who by nature should guide him are in disagreement among them, [the infant] should have the Church come to his aid by always preferring the sentiment of the person who will assure his salvation with Baptism." 67

As is clear from these cases, and the Mortara family plea, Aquinas's teaching was viewed by advocates of Jewish parental rights as a defense against forced baptism of children. The Roman lawyer Luti's plea is representative of the challenge since it highlights that Aquinas's teaching was known but it was ineffective in the face of appeals to higher loyalties or the favor of the faith. ${ }^{68}$ Luti wrote:

But if things continue in this manner, we shall soon see the offering of any relative approved, not to mention any Jew in the Ghetto, and the opinion of St.

\footnotetext{
Baptism: Histories of Jews, Christians, and Converts in Papal Rome (Los Angeles: University of California Press, 2012), 119-20; Walter Pakter, Medieval Canon Law and the Jews (Verlag Rolf Gremer, 1988), 319.

${ }^{64}$ Caffiero, 83. Jews of the Roman ghetto regularly relied upon Christian lawyers because Jews could not exercise the liberal professions.

${ }^{65}$ Caffiero, 84-5.

${ }^{66}$ Caffiero, 117.

${ }^{67}$ Caffiero, 121.

${ }^{68}$ Caffiero, 19.
} 
Thomas, which is said to be followed, will have only the honor of being commonly printed in the books, but will be trampled on the more and more when it comes to putting it into practice. ${ }^{69}$

Contemporary reactions to Cessario's essay also view Aquinas as opposed to forced baptism of children. However, based on the papal counsel's appeal to Aquinas, it seems there are texts in the Summa theologiae that lend support to Pius IX's decision to remove Edgardo from his parents. Who has the correct interpretation of Aquinas? As discussed above, the earlier controversy presents a difficulty. Does Aquinas teach that baptism invitus parentibus is licit in certain exceptions? Is an illicit baptism nevertheless valid, on his terms?

To adequately treat Aquinas's thought is beyond the scope of this essay since it requires setting his views in the context of medieval and early modern canon law on forced baptism of Jewish children, as well as thirteenth-century theological disputes on baptism invitus parentibus. I have examined Aquinas's teaching in these contexts in another study. ${ }^{70}$ Here, I want to briefly explain why Aquinas is cited by both sides in the 1858 debate, and why I think it is misleading to cite Aquinas in support of Pius IX's decision to abduct Edgardo Mortara.

Toward the end of Aquinas's career, and in part because of the discovery of the Talmud, a campaign to take Jewish children from their parents emerged. French Dominicans in particular sought to remove Jewish children so they might be raised as Christians. Aquinas addressed the question of whether children of Jews should be baptized invitus parentibus in II-II 10.12 as a response to this controversy. He asks, should the children of Jews or other unbelievers be baptized against their parents' wishes? His answer is negative. But at first glance, it seems Aquinas teaches that an unlawful baptism is nevertheless valid, and results in loss of parental rights over the children. This is because he writes, in the sed contra of this article, "Now it would be an injustice to Jews if their children were to be baptized against their will, since they would lose the rights of parental authority over their children as soon as these were Christians." Indeed, the papal counsel interprets this text to mean that Aquinas thinks parents lose their rights as soon as their children are baptized:

Saint Thomas himself asserts that the Church never had the custom to baptize the sons of the infidels against the wishes of the parents, and, among other reasons, says that since the parents would lose each right on the sons who would be passed to the authority of the Church by force of the Baptism. However, wrong would be done to the Jews, if their children were baptized without their consent, because they would lose the right of paternal power over their children now Christians. ${ }^{71}$

\footnotetext{
${ }^{69}$ Caffiero, 120.

${ }^{70}$ Matthew Tapie, "Spiritualis Uterus: Thomas Aquinas's Defense of Jewish Parental Rights," The Bulletin of Medieval Canon Law vol. 35, 2018.

${ }^{71}$ Stahl, 100.
} 
However, such a misinterpretation of Aquinas's position is due to inattention to the dialectical style of the disputatio. In the Summa theologiae, Aquinas carefully list the positions on either side of a question. The "objections" listed in the first part of the article contain the arguments against his answer to a question. Then he sets the sed contra, which is opposed to the objections. The sed contra can easily be mistaken for Aquinas's position because the sed contra typically represents something close to Aquinas's position (against baptism of children invitus parentibus). However, it is inadequate on its own since Aquinas may only agree with part of it. Indeed, it seems the argument that Aquinas places in the sed contra is the preferred legal argument of the day against forced baptism of Jewish children; but this preferred argument of the day assumed the legal consequences of coerced baptisms in the thirteenth century since it states that parents lose their rights over the children once these are baptized. The papal counsel's appeal to this notion that parents' lose their rights only appears in the sed contra, and is therefore a proof text.

It is only in his respondeo and replies to objections that one can determine Aquinas's answer to a question. Aquinas's answer is referred to as the respondeo, and it comes after the sed contra; his answer (as well his replies to the objections, which come last) is similar to the sed contra in that he is also opposed to forced baptism of Jewish children. But his answer is different in that he presents an elaborate theological defense of Jewish parental rights in which he synthesizes the Roman legal tradition of patria potestas (parental rights) with the theological concept of the natural law. In Aquinas's day, French Dominicans advocated for forced baptism of Jewish children for numerous theological reasons, including the argument that those who can baptize Jewish children must do so because the immortal souls of the children are in danger. French Dominican William of Rennes (ca. 1259), who was followed by Vincent of Beauvais (d. 1264) articulated this view, a view Aquinas actually lists in the objections in this article. ${ }^{72}$ Aquinas's reason for rejecting such theological arguments for baptizing Jewish children against the will of their parents is that such practice is "repugnant to natural justice." Natural justice was the equivalent of natural law. "Hence it would be contrary to natural justice, if a child, before having the use of reason, were to be taken away from its parents' care, or to have anything done to it if the parents are unwilling." For Aquinas, forced baptism and stealing children from parents are both contrary to natural justice. Additionally, in other texts concerning his theology of baptism, Aquinas teaches that a valid baptism requires the intention of the recipient, which implies that a forced baptism without the intention of the parents is an invalid baptism. ${ }^{73} \mathrm{In}$ other words, the Dominican theologians cited by the Mortara family, and who ask "Who's will is the will of the child?" interpret Aquinas correctly when they argue that a forced baptism of a child is invalid on his terms. This, in part, is why Aquinas

\footnotetext{
${ }^{72}$ II.II 10.12 ad. 2: "[N]no one ought to break the order of the natural law, whereby a child is in the custody of its father, in order to rescue it from the danger of everlasting death."

${ }^{73}$ I.II 111.2 ad. 2; III 68.7 ad. 2; III 64.8 ad. 2.
} 
holds that before the child has use of reason, it can be baptized only if the parents will this. $^{74}$

I have tried to show that the question of Aquinas's teaching in the contemporary conversation on the Mortara affair can be clarified through an analysis of the concerns in the 1858 debate. The difficulty that emerges in this original dispute is that Aquinas is claimed by both sides. Adjudicating this issue requires specification of two questions in Aquinas's theology of baptism: whether Aquinas teaches that baptism of the children of unbelievers invitus parentibus is lawful in certain exceptions, such as danger of death, and whether an unlawful baptism is nevertheless valid, on his terms. In so far as Aquinas's teaching is concerned, the baptism of Edgardo Mortara, or any child against the will of their parents, is not valid, lawful, or praiseworthy, but a dangerous innovation contrary to the custom of the Church and the natural law. After a reading of Aquinas's teaching in the context of the scholastic genre of the disputed question, it is clear that the citation of the sed contra is a proof text for the papal counsel's position, and not Aquinas's view. The problem with this reading of Aquinas is that it misinterprets the sed contra for Aquinas's answer to the question in II.II 10.12, and reads the statement out of the context of the rest of his teaching on baptism. The reading also ignores his teaching that baptism of a child against the will of parents, even to save it from spiritual death, is against the natural law. Aquinas's teaching, therefore, denies the rationale for theologies that argue for baptism of children invitus parentibus in danger of death.

\footnotetext{
${ }^{74}$ As I explain in Spiritualis Uterus, however, the debate among canonists and theologians in Aquinas's time was not on whether a forced baptism could be considered valid but whether forced baptisms could be considered lawful.
} 